\title{
Custom amalgamation for civic learning in elementary school: Cultural citizenship literacy viewpoint on Minangkabau ethnic tradition
}

\author{
S.I. Hamid, T. Istianti, M.H. Ismail \& F.H. Firmansyah \\ Universitas Pendidikan Indonesia, Bandung, Indonesia \\ F. Abdillah* \\ Universitas Negeri Jakarta, East Jakarta, Indonesia
}

\begin{abstract}
This study aimed to explain teachers' efforts into cultural literacy citizenship of integrating Minangkabau local wisdom to civic education in elementary schools. The research was conducted with a qualitative approach to Minangkabau cultural artifacts such as literature, speech, and customs. The ethno pedagogical approach was also used to examine the substance and cultural strategy of learning by fourth-grade teachers from two schools selected purposely. The research findings illustrated that teachers' success in developing learning with a literacy cultural citizenship orientation was supported by students' cultural homogeneity, teachers as native, and teacher competence. The third finding provides an insight that contextualization, a sense of belonging to a culture, and teacher professionalism need to be considered in developing cultural citizenship literacy-oriented learning. Thus, the study recommends that attention is needed for a multicultural and multiethnic context so that more local and national cultures can be introduced in teacher training institutions.
\end{abstract}

Keywords: amalgamation, civic learning, elementary school, cultural citizenship

\section{INTRODUCTION}

The Minangkabau ethnicity's cultural and political identities have been recorded in the history of the Indonesian nation's journey. The nation's founders and national figures from the Minangkabau ethnicity such as Mohammad Mohamad Hatta, M. Yamin, M. Natsir, Sutan Syahrir, Agus Salim, Tan Malaka, to Buya Hamka made significant contributions to the field (Abdullah 2009; De Jong 2012). In education, Mohammad Sjafei through the concept of the Inlander Netherland School (INS) Wood Planting Education in West Sumatra. This background becomes a reinforcing element that cultural literacy-based education development studies can develop with the Minangkabau ethnic background. Social, political, and cultural aspects have positions and implications for the richness of content and learning approaches. In education, the concept of ethno pedagogy, which uses all elements of culture for education, is known as an orientation and foundation for the development of Pancasila and Civic Education (PPKn) learning, Citizenship Cultural Literacy needs to depart from the aspects of the cultural wealth of the Minangkabau ethnicity.

Based on previous studies (Abdillah et al. 2017; Hamid 2016; Hamid \& Istianti 2012; Hamid et al. 2019), this research intended to examine idioms and artistic expressions from Sundanese, Javanese, Sasak, Bugis, and Minangkabau ethnicities. Take as an example the case of education in elementary schools where idioms in Sundanese have been projected to be used in an integrated manner in Pancasila and Civic Education subjects (Abdillah, et al. 2017). In order to meet these needs, the enrichment of cultural sources of the Minang ethnic group is taken into account as the

${ }^{*}$ Corresponding Author 
prospect of expanding and developing Pancasila and Civic Education learning. Reactualization takes the form of learning models continually being developed and adjusted to actual, measurable, concrete, not merely administrative targets. Moreover, the concept of cultural citizenship is also a dilemmatic partial effort in responding to globalization (Duncker 2015). This is also a form of avoiding negative impacts on social cohesion and government performance (Hlepas 2013). Thus, a Citizenship Cultural Literacy Model was developed with ethnic idioms that were used to enrich learning materials (Abdillah et al. 2017).

As one of the primary and general subjects in schooling institutions, citizenship education has curricular fulfilled its function and role, fulfilling the instrumentation of instilling national moral and political values throughout the history of education and the dynamics of political development itself. Therefore, the emergence of conceptual residues and a reduction in the achievement of meaning in a particular situation and period is possible. However, it can be saved from its latent function as a medium for strengthening and restoring essential values whose sources are stored in the artifacts of local cultural life. The substance of character development departs from public culture (Lee 2013). In the political structures and public policies, it is obligatory to foster community participation and the fostering program is supported by a supportive civic culture for the emergence of citizen involvement (Docherty et al. 2001). Therefore, developing Citizenship literacy based on local traditions is important and strategic in multiplying PPKn learning in schools as political and moral education and modeling and mediation of local cultural products, both homogeneous and integral, based on the diversity of the archipelago.

In this study, we examined the implementation of local wisdom values derived from the customs of the life of the Minangkabau people of West Sumatra. The examination is seen from the perspective of citizenship literacy in the curriculum map in elementary schools and the implementation of the praxis model of citizenship literacy learning based on local Minangkabau traditions in Civic Education and Pancasila at elementary school grade IV-V in Padang City, West Sumatra.

\section{METHODS}

This study applied the qualitative approach to analyze Minangkabau cultural artifacts. The artifacts include literary works, customs, and idioms. In expressing the analysis results of learning, the ethno pedagogical approach was used to enrich the substance and strategy with a cultural context. The cultural context was then framed with the concept of Moral Citizenship Value (Hamid 2015) as a material for learning. The selection of primary schools was selected purposely to capture the conditions to be understood further. Four teachers were then selected purposely by considering the proximity of the school to the traditional center and being close to urban areas. The data collected was then analyzed using data triangulation to obtain representative and sufficient data to present findings. The teacher was first given training in the implementation of the civic literacy development model, then the teacher immediately practiced it in his PPKn class together with all the learning tools. After this implementation, the teacher was then interviewed. The interview is about the activities he implemented. Then, the students were interviewed on a limited basis to see their impressions of the learning. In the final session of this step, the researcher analyzed the framework of the concept of the moral value of citizenship.

\section{RESULTS AND DISCUSSION}

\subsection{Implementation of the development of the moral value concept of citizenship based on the cultural typology of the Minang community}

\subsubsection{Description of the content of the NMK concept in Minangkabau culture}

Ethnic communities Minangkabau, as one of those tribes who have a wealth of cultural, the actualization of collective belief and performance behavior everyday both in the homeland and overseas 
based on the actualization of the social and its role in the dynamics of community life, (economic, political, cultural, and the professions generally) the field livelihoods, can be marked to represent the ethnic group that is strong in preserving the customs and traditions of heritage ninik mamak (Abdullah 2009; De Jong 2012). Over time and future development, no doubt the community is experiencing scour changes, a decrease in cohesion above the reference value. The teacher has been viewed as an educator and a member of society that is more educated than the general population. The teacher is a central figure who has a higher literacy level towards the fluctuation of the temperature of civilization and the civilization of society in responding to the challenges to his era (Lee 2013). Teacher against Cultural iteration as the basis of developing life praxis values that can be incorporated into the curricular learning format is strong enough to be believed as the right choice (Docherty et al. 2001).

Table 1 below shows expressions used as the cultural beliefs of the Minang people. These expressions are recommended to being understood in the sense that both the concept and the content-message are raised. After being classified and codified based on the NMK-7 Analysis Model Ichas (Hamid 2015), this classification becomes a content of civic cultural literacy in the design of elementary school Civic Education and Pancasila learning. It is essential to raise them fill out the Development of Citizenship Literacy Teaching Materials into PPKn Learning Designs in Elementary Schools.

Table 1. Recommended local wisdom phrases.

\begin{tabular}{|c|c|c|c|c|}
\hline No & Local Phrases & Contents & Classification & Coding \\
\hline \multirow[t]{4}{*}{1} & $\begin{array}{l}\text { Ombak barayun manuju pantai, riak nyato manuju } \\
\text { tapi. Indak guno jadi rang pandai, kalau baulemu } \\
\text { indak babudi }\end{array}$ & $\begin{array}{l}\text { There is no meaning to having intelligence if you are } \\
\text { not virtuous }\end{array}$ & $\begin{array}{l}\text { Humble, Know-yourself. } \\
\text { Patience, Sincerity: (4) }\end{array}$ & MK1-1 \\
\hline & $\begin{array}{l}\text { Panjang namuah dikarek senteng namuah dibilai, } \\
\text { singkek namuah diuleh, kurang namuah ditukuak }\end{array}$ & $\begin{array}{l}\text { Willing to accept advice and acknowledge } \\
\text { shortcomings }\end{array}$ & & MK1-2 \\
\hline & $\begin{array}{l}\text { Pucuak pauah sadang tajelo, panjuluak buah ligundi, } \\
\text { nak jauah silang sangketo, pahaluih baso jo basi }\end{array}$ & Language ethics and courtesy to avoid cross dispute & & MK1-3 \\
\hline & $\begin{array}{l}\text { Hiduik batungkek batang bodi, mati bapuntiang } \\
\text { ditanah sirah. Jikok pandai bamain budi, dalam } \\
\text { aia badan indak basah. }\end{array}$ & $\begin{array}{l}\text { The virtue of having a mind brings advantages to an } \\
\text { association. }\end{array}$ & & MK1-4 \\
\hline \multirow[t]{7}{*}{2} & Nak elok lapangkan hati, nak haluih baso jo basi. & $\begin{array}{l}\text { People always be patient, and people respect } \\
\text { acceptable language. }\end{array}$ & $\begin{array}{l}\text { Big-hearted, Honest, } \\
\text { Open: (7) }\end{array}$ & MK2-1 \\
\hline & $\begin{array}{l}\text { Nak luruih rantangkan tali, luruih bana dipacik } \\
\text { sungguah }\end{array}$ & $\begin{array}{l}\text { Be upright and sincere in relationships, uphold the } \\
\text { truth of honesty. }\end{array}$ & & MK2-2 \\
\hline & $\begin{array}{l}\text { Nanang saribu aka, haniang ulu bicaro, pikia palito } \\
\text { hati, dek saba bana mandatang. }\end{array}$ & $\begin{array}{l}\text { The calmness of thought raises good aspirations, and } \\
\text { patience brings truth. }\end{array}$ & & MK2-3 \\
\hline & $\begin{array}{l}\text { Nan elok dek awak katuju dek urang, sakik dek awak } \\
\text { sakik dek urang. }\end{array}$ & Do and behave to please the crowd. & & MK2-4 \\
\hline & Sabanta sakalang hulu, salapiak sakatiduran & Friendship & & MK3-5 \\
\hline & $\begin{array}{l}\text { Satali pambali kumayan, sakupang pambali katayo, } \\
\text { sakali lancuang kaujian, salamo hiduik urang indak } \\
\text { picayo }\end{array}$ & People will no longer trust one person cheating forever. & & MK2-6 \\
\hline & $\begin{array}{l}\text { Syarak banamo lazim, adat nan banamo kewi, habih } \\
\text { tahun baganti musim, buatan nan usah diubahi. }\end{array}$ & $\begin{array}{l}\text { Obeying a joint decision no matter how difficult and } \\
\text { bitter it is to accept it }\end{array}$ & & MK2-7 \\
\hline \multirow[t]{10}{*}{3} & Nan barek samo dipikua, nan ringan samo dijinjiang. & always cooperate in doing good & Friendship, loyality: (10) & MK3-1 \\
\hline & Olak olai rang basiang, sorak sorai rang karimbo. & $\begin{array}{l}\text { The excitement of working together with joy lightens } \\
\text { the work. }\end{array}$ & & MK3-2 \\
\hline & $\begin{array}{l}\text { Padanggantiang baranah-ranah, kahilia jalan } \\
\text { kapianggu, sasimpang jalan kasikabu Duduak samo } \\
\text { randah tagak samo tinggi dalam adat Minangkabau }\end{array}$ & $\begin{array}{l}\text { Does not differentiate human dignity unless the deeds } \\
\text { conform to custom }\end{array}$ & & MK3-3 \\
\hline & $\begin{array}{l}\text { Partamo banamo Minang, Minangkabau namo kaduo, } \\
\text { nan kayo mandi baranang, nan bansaik bandi batimbo }\end{array}$ & $\begin{array}{l}\text { Cooperation and the spirit of sacrifice according to } \\
\text { their respective abilities }\end{array}$ & & MK3-4 \\
\hline & Senteang bilai mambilai, panjang karek mangarek & $\begin{array}{l}\text { Provide help to friends who are in distress, and provide } \\
\text { advice if needed }\end{array}$ & & MK3-5 \\
\hline & Saumpamo aua jo tabiang, umpamo ikan jo aia. & $\begin{array}{l}\text { The excellent association helps each other and } \\
\text { strengthens and needs each other. }\end{array}$ & & MK3-6 \\
\hline & $\begin{array}{l}\text { Tatungkuik samo makan tanah, tatilantang samo } \\
\text { minum ambun, tarapuang samo hanyuik, tarandam } \\
\text { samo basah. }\end{array}$ & Good cooperation in society, one heart, and mind & & MK3-7 \\
\hline & Titiak buliah ditampuang, maleleh buliah dibaliak. & $\begin{array}{l}\text { The result of good cooperation to be enjoyed by many } \\
\text { people. }\end{array}$ & & MK3-8 \\
\hline & Duduak sahamparan makan saedangan & Sit in one place, eat the same dish. & & MK3-9 \\
\hline & Dimana bumi dipijak disinan langik dijunjuang & Where we are, we can adjust & & MK3-10 \\
\hline
\end{tabular}


Table 1. Recommended local wisdom phrases. (Continued)

\begin{tabular}{|c|c|c|c|c|}
\hline No & Local Phrases & Contents & Classification & Coding \\
\hline \multirow[t]{7}{*}{4} & Naiaklah dari janjang, turunlah dari tanggo. & $\begin{array}{l}\text { Always act according to applicable rules, according to } \\
\text { custom, religion, and state law. }\end{array}$ & $\begin{array}{l}\text { Respect, obeying the law, } \\
\text { being alert, vigilant, } \\
\text { (devotion): (7) }\end{array}$ & MK4-1 \\
\hline & $\begin{array}{l}\text { Nak jan jauah panggang dari api, latakkan sasuatu } \\
\text { ditampeknyo }\end{array}$ & Professionalism & & MK4-2 \\
\hline & $\begin{array}{l}\text { Raso aia kapamatang, raso minyak kakuali, nan } \\
\text { bakabek rasan tali, nan babungkuih rasan daun }\end{array}$ & The spirit of defending family honor & & MK4-3 \\
\hline & Suri tagantuang ditanuni, luak taganang kito sauak & $\begin{array}{l}\text { customary teachings that are absolutely implemented, } \\
\text { without deliberation }\end{array}$ & & MK4-4 \\
\hline & $\begin{array}{l}\text { Sandi banamo alua adat, tonggak banamo } \\
\text { kasandaran }\end{array}$ & $\begin{array}{l}\text { The wisdom of a traditional house, which itself is a } \\
\text { shared truth, the strong support of its customary law }\end{array}$ & & MK4-5 \\
\hline & Siang manjadi tungkek, malam manjadi kalang & $\begin{array}{l}\text { We should hold and practice every good lesson and } \\
\text { parental advice. }\end{array}$ & & MK4-6 \\
\hline & $\begin{array}{l}\text { Tak ujuang pangka mangganai, saragi baliak } \\
\text { batimba. }\end{array}$ & $\begin{array}{l}\text { Someone who has complete knowledge and tools, } \\
\text { which can be used multi-purpose. }\end{array}$ & & MK4-7 \\
\hline \multirow[t]{3}{*}{5} & $\begin{array}{l}\text { Nan mudo pambimbiang dunia, nan capek } \\
\text { kaki ringan tangan, acang-acang dalam nagari. }\end{array}$ & $\begin{array}{l}\text { Youth, the hope of the nation in the hands of youth lies } \\
\text { in the progress and retreat of the nation in the future. }\end{array}$ & $\begin{array}{l}\text { smart, careful, brave, and } \\
\text { officer: ( } 3 \text { ) }\end{array}$ & MK5-1 \\
\hline & $\begin{array}{l}\text { Partamo cupak usali, kaduo cupak buatan. } \\
\text { Kalau dulu disasali manjadi tuah pandapatan. }\end{array}$ & Regret first income, regret then useless. & & MK5-2 \\
\hline & Pikia palito hati, tanang hulu bicaro & $\begin{array}{l}\text { A thought that has judgment is an antidote. A light } \\
\text { illuminates the heart, and serenity will give off good } \\
\text { speech. }\end{array}$ & & MK5-3 \\
\hline \multirow[t]{8}{*}{6} & $\begin{array}{l}\text { Ombak ditantang manuju pulau, laia dikambang } \\
\text { manantang angin }\end{array}$ & $\begin{array}{l}\text { To achieve a goal and ideals always experience trials } \\
\text { and obstacles }\end{array}$ & $\begin{array}{l}\text { Resilient, steady, hard } \\
\text { work, tough (reliable): (6) }\end{array}$ & MK6-1 \\
\hline & Pandai karano batanyo, tahu karano baguru. & $\begin{array}{l}\text { Knowledge is argued for because of learning, } \\
\text { education, and asking a lot of questions from people } \\
\text { who know. }\end{array}$ & & MK6-2 \\
\hline & $\begin{array}{l}\text { Sadang manyalam minum aia, sadang badiang nasi } \\
\text { masak }\end{array}$ & $\begin{array}{l}\text { Something work that can be done casually, and does } \\
\text { not detract from the work that is being done }\end{array}$ & & MK6-3 \\
\hline & Satitiak jadikan lauik, sakapa jadikan gunuang & $\begin{array}{l}\text { Strive with the existing knowledge base to continue to } \\
\text { achieve higher knowledge }\end{array}$ & & MK6-4 \\
\hline & $\begin{array}{l}\text { Sadang baguru kapalang aja, lai bak bungo } \\
\text { kambang tak jadi. Kunun kok dapek dek mandangga, } \\
\text { tidak didalam dihalusi. }\end{array}$ & $\begin{array}{l}\text { Every time you demand knowledge, don't break the } \\
\text { road, study hard. }\end{array}$ & & MK6-5 \\
\hline & Tabujua lalu tabalintang patah. & To defend the truth, take it with utter persistence. & & MK6-6 \\
\hline & $\begin{array}{l}\text { Dak ado rotan akapun jadi dak ado kayu } \\
\text { janjang dikapiang }\end{array}$ & Can find solutions at critical times & & MK6-7 \\
\hline & $\begin{array}{l}\text { Walau kaia yang dibantuak ikan di lauik } \\
\text { nan dihadang }\end{array}$ & We need planning to achieve success. & & MK6-8 \\
\hline \multirow[t]{8}{*}{7} & $\begin{array}{l}\text { Ingek di rantiang ka mancucuak, Tahu didahan ka } \\
\text { maimpok }\end{array}$ & Wise & $\begin{array}{l}\text { Fair, wisdom, guarding } \\
\text { (Leadership) (5) }\end{array}$ & MK7-1 \\
\hline & Maukua samo panjang, mambilai samo laweh & Fair & & MK7-2 \\
\hline & $\begin{array}{l}\text { Nansakik iyolah kato, nan padiah iyolah rundiang. } \\
\text { Dek tajam nampak nan luko, dek kato hati taguntiang }\end{array}$ & $\begin{array}{l}\text { The word that hurt was more dangerous than a sharp } \\
\text { knife. }\end{array}$ & & MK7-3 \\
\hline & $\begin{array}{l}\text { Pado pai suruik nan labiah, samuik tapijak indak } \\
\text { mati, alu tataruang patah tigo }\end{array}$ & $\begin{array}{l}\text { Be your ideal young man, calm, decisive, smart, agile, } \\
\text { wise, and high-minded. }\end{array}$ & & MK7-4 \\
\hline & Sakalam kalam hari sabuah bintang bacahayo juo. & There are always exceptions. & & MK7-5 \\
\hline & Satuntuang tabu dek ulek, satuntuang sajo kito buang & A person makes mistakes, lest all the family be hated. & & MK7-6 \\
\hline & Tagak indak tasundak, malenggang indak tapampeh. & A leader who has full authority and authority. & & MK7-7 \\
\hline & & & 42 & \\
\hline
\end{tabular}

\subsubsection{Development of citizenship literacy learning message content based on Minang local wisdom in grade IV elementary school}

The development of Citizenship Literacy Learning content refers to the curriculum map for PPKn subjects in elementary schools, formally regulated by the Regulation of the Minister of Education and Culture Number 103 of 2014 concerning Curriculum 2013. Apart from the dynamics that are the place and formal reference for implementing learning in schools, especially concerning PPKn subjects in elementary schools (Abdillah, et al. 2017). As subjects that occupy the foundation and are common to schooling, as in the history of education in the country, as far as change is rationalized as an effort to adjust the strategic achievements of planting moral values within the framework of National Education which is oriented towards the formation of good character of citizens by the philosophy of Pancasila and competence in the sense of being smart and skilled to be able to face the demands of the progress and challenges of the era. Along with the mapping of 
educational goal achievement points that students must achieve as teaching subjects in schools, the necessary and actual competencies that teachers must have as learning facilitators are an integral part of continuous adjustment and development efforts. In this section, the results of the analysis of the curriculum map in primary schools will be mapped with the demands for necessary skills and innovation of class (IV) teachers in developing conceptual materials and the choice of models and media required.

Table 2. Analysis of the concept of value content and the choice of approach and media.

\begin{tabular}{|c|c|c|c|c|}
\hline \multirow[b]{2}{*}{ No. } & \multirow[b]{2}{*}{ Material concept } & \multirow[b]{2}{*}{ Load moral values } & \multicolumn{2}{|l|}{ Selection } \\
\hline & & & Approach & Media \\
\hline 1 & $\begin{array}{l}\text { The meaning of the relationship } \\
\text { between the Garuda symbol and } \\
\text { the Pancasila principles }\end{array}$ & $\begin{array}{l}\text { Aspiring noble, } \\
\text { virtuous knights/ } \\
\text { good deeds }\end{array}$ & Integrated thematic & $\begin{array}{l}\text { Image/animation } \\
\text { Stories, movies } \\
\text { Game }\end{array}$ \\
\hline 2 & $\begin{array}{l}\text { Implementation of obligations } \\
\text { and rights as citizens of society }\end{array}$ & $\begin{array}{l}\text { The habit of being } \\
\text { fair }\end{array}$ & $\begin{array}{l}\text { Integrated thematic - } \\
\text { scientific }\end{array}$ & $\begin{array}{l}\text { Image/animation } \\
\text { Stories, movies } \\
\text { Game }\end{array}$ \\
\hline 3 & $\begin{array}{l}\text { The diversity of religious } \\
\text { communities in society }\end{array}$ & $\begin{array}{l}\text { Tolerance to } \\
\text { differences }\end{array}$ & Integrated thematic & $\begin{array}{l}\text { Image/animation } \\
\text { Stories, movies } \\
\text { Game }\end{array}$ \\
\hline 4 & $\begin{array}{l}\text { Forms of ethnic, social, and cultural } \\
\text { diversity in Indonesia which } \\
\text { are bound by unity and integrity }\end{array}$ & $\begin{array}{l}\text { Togetherness as } \\
\text { one nation }\end{array}$ & Integrated thematic & $\begin{array}{l}\text { Image/animation } \\
\text { Stories, movies } \\
\text { Game }\end{array}$ \\
\hline
\end{tabular}

\subsection{Implementation of citizenship literacy PPKn learning based on homogeneous ethnic social culture of Minangkabau, West Sumatra}

In the realm of Minang as the parent of the preservation of the local culture where Ninik Mamak is institutionally located, the Minangkabau community can be described as water flows upstream if the Minang people in overseas lands such as on the island of Java show the strength of their customs and language as a reflection of culture. No doubt upstream, especially the city of Padang, West Sumatra, whereas the city of Padang, now as one of the provincial capitals, is like showing progress like other big cities in the country, the inhabitants of Padang city in various professions, including teachers, are no different like the Minang people in Jakarta, Bandung, Yogyakarta, and other cities strongly speak their mother tongue if talk to other people from his village - as Urang Awak. However, he also speaks the language of the area where he is, for example, Javanese, Sundanese, Betawi, and standard Indonesian. With this socio-cultural background, there are no obstacles, even arguably in the West Javanese expression "mobok cadas manggih gorowong" which means, "finding a way to meet an open door" in mobilizing elementary school class teachers with Minang ethnic backgrounds to apply the Citizenship Literacy learning model based on local traditions in culture and local language, namely Minangkabau.

Even though the Minang realm is known as a hotbed of ethnic migrants (Docherty et al. 2001), with the extensive urban socio-geographical conditions, schools and educational institutions are scattered in the middle and corners of the city. The public and the private sector are racing to provide quality services for the needs of the community. The city of Padang as the center of Government, development of Education and Culture as well as a city of commerce and trade which is open to the entry of other ethnic migrants from all over the archipelago. With these biographical conditions , what teachers do relate to the development of local wisdom-based citizenship literacy is not the only potential for the development of homogeneous values of Minang language and culture (Hlepas 2013). It allows to be integral to the integration stage of diversity values by including a comparison 
of local wisdom value in the language, songs, and other Indonesian ethnic games (Abdillah et al. 2017; Hamid 2016; Hamid \& Istianti 2012; Hamid et al. 2019).

\section{CONCLUSIONS}

Three prominent factors influence the smooth process of cultural integration in learning in the PPKn subject. The first factor is cultural homogeneity in schools, which is dominated by local people of the same ethnicity, namely the Minangkabau. This homogeneity is supportive because teachers find it helpful to focus on developing teaching and learning materials. The second factor, teachers as indigenous people, so that what is developed is based on authentic cultural experiences in civic learning. The third factor, teacher competence, is the main thing to cultivate and organize the two previous supporters. This research implies that there needs to be a multicultural and multiethnic context so that more local and national cultures can be introduced. Also, teacher training is an aspect that also needs attention.

\section{REFERENCES}

Abdullah, T. 2009. Schools and Politics: The Kaum Muda Movement in West Sumatra (1927-1933). Equinox Publishing.

Abdillah, F. et al. 2017. Ethnic Idiom Articulation and Civic Education Material for Elementary School Development of Cultural Citizenship Literacy. In 1st International Conference on Educational Sciences ICES: 225-229. Bandung: ScitePress.

Duncker, K. 2015. Cultural citizenship: Understanding the natural states of freedom participation and equality in light of societies self-awareness, -contemplation and -reflection through culture and cultural evolutionary learning by mode of media. Florence: European University Institute.

De Jong, P.D.J. 2012. Minangkabau and Negri Sembilan: socio-political structure in Indonesia. Berlin: Springer Science \& Business Media.

Hamid, S.I. 2015. Nilai moral kewarganegaraan dalam artefak kehidupan sosial kultural masyarakat sunda: Studi eksploratif nilai moral kewarganegaraan dalam ungkapan, artikulasi seni dan ritual adat Budaya Sunda. Bandung: Sekolah Pascasarjana.

Hamid, S.I. 2015. Semiotika Pendidikan Kewarganegaraan dalam tradisi lokal Sunda. Bandung: Rizqi Press.

Hamid, S. I. \& Istianti, T. 2018. Pengembangan pembelajaran PPKn di SD-MI. Bandung: UPI Kampus Cibiru.

Hamid, S.I. \& Istianti, T. 2012. Rekonstruksi nilai moral kewarganegaraan berdasar analisis semantik terhadap ungkapan kultural masyarakat Sunda. Cakrawala Dini: Jurnal Pendidikan Anak Usia Dini 3(2): 1-21.

Hamid, S. I. et al. 2019. Mengurai konstelasi filosofis Pancasila melalui literasi budaya kewarganegaraan dan literasi digital kewarganegaraan. In Prosiding Seminar Pendidikan Nasional Membangun Pendidikan Berbasis Paradigma Higher Order Thinking Skills dalam Konteks Keindonesiaan. Bandung: UPI Kampus Cibiru.

Hlepas, N. 2013. Cultural diversity and national performance. Athens: International Centre for Black Sea Studies (ICBSS).

Lee, T. 2013. Public culture and cultural citizenship at the Thessaloniki International Film Festival. Cambridge: Harvard University.

Miller, T. 2002. Cultural citizenship. In E.F. Isin \& B. Turner (Eds.), Handbook of Citizenship Studies: 231244. London: Sage Publications Ltd.Permata, A. 2015. Membangun kualitas bangsa dengan budaya literasi. In Prosiding Seminar Nasional Bulan Bahasa: 148. Bandung: Universitas Bandung.Hamid, S.I. 2016. A Description of Citizenship Moral Values in Sundanese Society. Man in India 96(12), 5125-5141.

Docherty, I. et al. 2001. Civic Culture, Community and Citizen Participation in Contrasting Neighbourhoods. Urban Studies, 38(12), 2225-2250. 